- Entomologica Fennica. 5 December 1995

\title{
Insects in burned forests - forest protection and faunal conservation (preliminary results)
}

\author{
Bengt Ehnström, Bo Långström \& Claes Hellqvist
}

Ehnström, B., Långström, B. \& Hellqvist, C. 1995: Insects in burned forests - forest protection and faunal conservation (preliminary results). - Entomol. Fennica 6:109-117.

The beetle colonization of fire-damaged trees was studied in seven reserves, which were established in burned forests in south and central Sweden, following extensive forest fires in the summer of 1992. In the spring of 1993, burned pine trees displayed a large range in fire damage from virtually undamaged ones to trees killed by the fire. Spruces were more sensitive than pine, and few fire-damaged spruces had some green foliage left. The pine shoot beetle, Tomicus piniperda (Linnaeus) was the main colonizer of pine trees, occurring at all sites, but altogether in only one-third of the trees. On spruce, two bark beetles were common: Polygraphus poligraphus (Linnaeus) was found on nearly all sites and altogether on half of the trees, followed in abundance by Pityogenes chalcographus (Linnaeus). These common species were accompanied by an assembly of bark and longhorn beetles, commonly occurring on fresh conifer timber. Most of the beetle species clearly preferred the dead or dying trees. However, the species mentioned above as well as Arhopalus rusticus (Linnaeus) also attacked trees with more than half of the foliage left. Three fire-favoured species were observed: Oxypteris (Melanophila) acuminata (Degeer), Sericoda (Agonum) quadripunctata (Degeer) and Pterostichus quadrifoveolatus (Letzner). Line surveys indicated little bark beetle dispersal from the burned areas into surrounding forests. Further studies are needed as the primary colonization of the burned trees was obviously not completed during this first year after the fire.

Bengt Ehnström \& Bo Långström, Swedish University of Agricultural Sciences, Department of Entomology, Division of Forest Entomology, P.O. Box 7044, S-750 07 Uppsala, Sweden

Claes Hellqvist, Swedish University of Agricultural Sciences, Department of Entomology, Division of Forest Entomology, S-776 98 Garpenberg, Sweden

\section{Introduction}

Intensified forestry practice during this century has turned the more or less virgin boreal forests of Sweden into well-managed and even-aged stands of pine and spruce (Heliövaara \& Väisänen 1984, Esseen et al. 1992, Linder \& Östlund 1992). Many insect species dependent on old, dying trees and dead wood material have become rare; a few have gone extinct and 


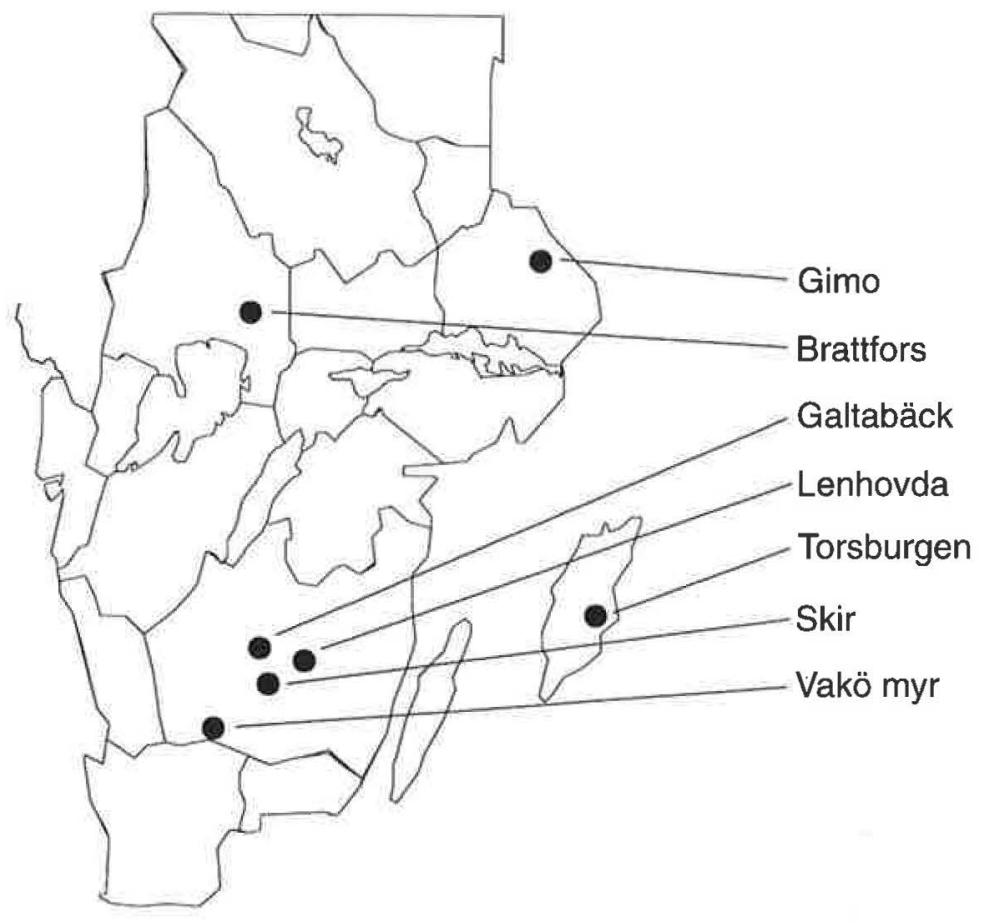

Fig. 1. Map of southern Sweden showing the location of the study areas many are now considered endangered (Ehnström et al. 1993). The lack of old trees and dead wood also affects other groups of organisms such as mosses, lichens, fungi and organisms related to these (Esseen et al. 1992, Berg et al. 1994). Thus, improving living conditions for all organisms dependent on old trees and/or dead wood is a major challenge for faunal and floral conservation in forestry.

A typical feature of the prevailing forestry practice is the lack of forest fires or even controlled burning, as it was practiced until recently (Zachrisson 1977). Many insect species adapted to forest fires and burned trees have decreased in numbers as these commodities have become increasingly rare in modern forests (Heliövaara \& Väisänen 1984, Lundberg 1984). Hence, reserves of burned forests are needed to promote living conditions for these fire-dependent species. On the other hand, burned forests may be suitable breeding grounds for forest pests such as bark beetles, and hence are less desirable from the perspective of forest protection. These conflicting views on forest fires triggered our interest to study burned trees as substrate for bark- and wood-living insects, especially beetles. Thus, our aims were to study: 1) the colonization of burned trees by bark beetles and other bark- and wooddwelling insects species; 2) how primary colonization depends on tree vigour; 3) and to establish background data on how later successional stages of insect colonization can relate to fire history and primary beetle invasion.

\section{Material and methods}

In 1992, an unusual number of large and small forest fires occurred in south and central Sweden. Several forest reserves were set aside in these burned areas, and seven of these were included in this study (Fig. 1).

The burned areas varied in size from a few hectares (Galtabäck) to more than 1000 hectares (Torsburgen and Vakö), and the reserved areas varied correspondingly (Table 1). At Lenhovda and Vakö, a large proportion of the burned area was peatland with a sparse forest cover, while other areas were fully stocked with coniferous forests of different age classes. Most burned forests were pine-dominated, except at Vakö where some spruce stands also became affected by the fire. The earliest fire took place on 10 June (Skir) and the latest on 23 July (Lenhovda). 
In the spring of 1993 , circular plots were laid out in the burned stands (except Torsburgen and Gimo, which were not inspected until the autumn 1993). The plot sites were selected to cover the range of fire damage and tree vitality of the dominating tree species in the area. Thus, we did not aim at estimating the average fire damage level, but to include the range in fire damage, and hence in substrate quality for bark- and woodliving insects. The number of plots varied from 3 to 12 depending on the size and variability of the fire area in question. Plot size was 100,200 or $300 \mathrm{~m}^{2}$ (radius: $5.64,7.98$ and $9.78 \mathrm{~m}$ ) depending on the stocking, and was selected to yield 10-15 trees per plot. On each plot, each tree exceeding $5 \mathrm{~cm}$ in diameter at $1.3 \mathrm{~m}$ stem height ("breast height") was numbered and its species and diameter was recorded. The vigour of each recorded tree was also noted according to the estimated amount of green foliage left on the tree using the following classes: $0,1-10,11-20,21-$ $40,41-60,61-80,81-100$ per cent of the pre-fire needle biomass still green on the tree.

After classifying tree vigour, all trees were inspected for boring dust indicating bark beetle attack, and notes were made on the presence or absence of boring dust. In a few cases, spruce trees had been attacked by the late-flying bark beetle Polygraphus poligraphus (Linnaeus) already in the previous summer, soon after the fire; notes were made on the developmental stages of these beetle attacks (see below). (In this paper, we use the nomenclature of Silfverberg 1992).
In the autumn 1993, plots were laid out at Torsburgen and Gimo as described above. On the other sites, all trees were re-inspected and re-classified with regard to the percentage of healthy foliage. On all sites, all trees were checked for presence/absence of exit holes indicating successful bark beetle colonization. Notes were also taken on the occurrence of the insect species of particular interest when occurring outside the sample plots.

On every third tree, a bark sample $(10 \mathrm{~cm}$ wide and $30 \mathrm{~cm}$ high) was inspected at knee height, breast height and three metres above the ground. In principle, the samples were taken on the side of the tree facing the centerpole of the plot, but the aspect was sometimes modified for practical reasons. On pine, all exit holes of pine shoot beetles (Tomicus piniperda (Linnaeus) and T. minor (Hartig)) were counted before the bark was removed. On spruce, no quantitative exit hole data were collected. All beetle galleries occurring under the bark were identified to species, and their occupancy of the bark area was estimated in $10 \%$ classes. The number of gallery systems of each occurring species was counted, and the developmental stages present in the galleries were recorded. On pine, we also measured the lengths of the egg galleries of the pine shoot beetles. Finally, the bark type was recorded as rough, intermediate or smooth, and the phloem vitality as dead, brownish and dry, white and dry and fresh (i.e. white and moist). When appropriate, the deviation of the trees from an upright position was recorded.

Table 1. Description of study areas.

\begin{tabular}{|c|c|c|c|c|c|c|c|c|c|c|c|}
\hline \multirow[t]{3}{*}{ Study area } & \multirow{3}{*}{$\begin{array}{l}\text { Burned } \\
\text { area, ha }\end{array}$} & \multirow{3}{*}{$\begin{array}{l}\text { Reserved } \\
\text { area, ha }\end{array}$} & \multirow{3}{*}{$\begin{array}{c}\text { Time of } \\
\text { fire }\end{array}$} & \multicolumn{4}{|c|}{ Scots pine } & \multicolumn{4}{|c|}{ Norway spruce } \\
\hline & & & & \multirow[b]{2}{*}{$n$} & \multicolumn{3}{|c|}{ diam o.b. (mm) } & \multirow[b]{2}{*}{$n$} & \multicolumn{3}{|c|}{ diam o.b. (mm) } \\
\hline & & & & & $x$ & $s$ & range & & $x$ & $\mathrm{~s}$ & range \\
\hline Brattfors & 189 & 75 & 29 June 1992 & 141 & 167 & 52 & $50-292$ & 1 & 154 & - & - \\
\hline Galtabäck & 7 & 7 & 9 July 1992 & 11 & 359 & 50 & $262-425$ & 20 & 199 & 79 & $83-359$ \\
\hline Gimo & 150 & 25 & 2 July 1992 & 83 & 126 & 32 & $64-201$ & 38 & 91 & 17 & $59-123$ \\
\hline Lenhovda & 48 & 10 & 23 July 1992 & 75 & 233 & 78 & $77-492$ & 40 & 172 & 88 & $72-359$ \\
\hline Skir & 65 & 2 & 10 June 1992 & 14 & 329 & 34 & 289-384 & 17 & 261 & 671 & $160-423$ \\
\hline Torsburgen & 1000 & 167 & 9 July 1992 & 130 & 227 & 69 & $87-391$ & 32 & 172 & 49 & $86-281$ \\
\hline Vakö & 1500 & 300 & 10 July 1992 & 64 & 203 & 63 & $97-337$ & 102 & 231 & 91 & $69-445$ \\
\hline Total & & & & 518 & 198 & 78 & $50-492$ & 250 & 192 & 91 & $59-445$ \\
\hline
\end{tabular}


In addition, all fallen pine shoots (due to pine shoot beetle attack) were counted on $10 \mathrm{~m}^{2}$ circular plots centered at the centre of the stand plots; counted shoots were removed outside the plot area. At Torsburgen and Brattfors, three and four transects, respectively, consisting of $10 \mathrm{~m}^{2}$ circular plots at $50 \mathrm{~m}$ intervals were laid out from the the edge of the burned areas in different directions into surrounding pine forests. All Tomicus-shoots found on the plots extending ca $500 \mathrm{~m}$ from the edge of the burned area were counted and removed.

\section{Results}

\subsection{Sample trees}

In the spring of 1993, the pine trees displayed a large range in fire damage from virtually undamaged ones to trees killed by the fire. However, no attempt was made to estimate the proportions of trees in different damage classes. Among our sample trees, the majority of the smaller trees had suffered severe foliage losses and many of them were classified as dead (Table 2). The spruces were obviously more sensitive to the fire than the pines, as most fire-affected spruce trees were dead or dying. As the pattern was similar at all sites, only pooled data are given.

The pine shoot beetle, $T$. piniperda was the most common colonizer of the pine trees, occurring at all sites, but altogether in only one third of the trees (Table 3). The longhorn beetles Acanthocinus aedilis (Linnaeus), Rhagium inquisitor (Linnaeus) and Arhopalus rusticus (Linnaeus) as well as the pine weevil Pissodes pini (Linnaeus). were also common. The occurrence of the bark beetle Pityogenes quadridens (Hartig) (as well as other species preferring the thin bark and branches) was certainly more frequent than the figures indicate, as it was not sufficiently well sampled by the technique used. It is noteworthy that Trypodendron lineatum (Olivier) and Monochamus sutor (Linnaeus) occurred in few sites and in low numbers.

On spruce, the bark beetle $P$. poligraphus was found on nearly all sites and altogether on half of the tree, followed in abundance by Pityogenes chalcographus (Linnaeus) (Table 4). The absence of Ips typographus (Linnaeus) is worth mentioning (although some attacks were observed on non-sample trees). Several of the bark and longhorn beetles attack both pine and spruce, and were consequently recorded on both species.

Table 2. Diameter distribution of trees in relation to crown vitality (i.e. percentage undamaged foliage) in spring 1993.

\begin{tabular}{|c|c|c|c|c|c|c|c|}
\hline \multirow[t]{2}{*}{ Tree species } & \multirow[t]{2}{*}{ Fresh biomass, \% } & \multicolumn{6}{|c|}{ Diameter class o.b., mm } \\
\hline & & -100 & -200 & -300 & -400 & $400+$ & Total \\
\hline \multirow[t]{6}{*}{ Scots pine } & 0 & 11 & 34 & 4 & 0 & 0 & 49 \\
\hline & $10-30$ & 7 & 73 & 50 & 14 & 2 & 146 \\
\hline & $40-60$ & 1 & 20 & 18 & 5 & 0 & 44 \\
\hline & $70-90$ & 0 & 22 & 30 & 12 & 1 & 65 \\
\hline & 100 & 0 & 0 & 0 & 1 & 0 & 1 \\
\hline & Total ${ }^{*}$ & 19 & 149 & 102 & 32 & 3 & 305 \\
\hline \multirow[t]{6}{*}{ Norway spruce } & 0 & 14 & 50 & 22 & 7 & 0 & 93 \\
\hline & $10-30$ & 0 & 12 & 21 & 16 & 2 & 51 \\
\hline & $40-60$ & 1 & 1 & 4 & 5 & 1 & 12 \\
\hline & $70-90$ & 0 & 1 & 4 & 3 & 1 & 9 \\
\hline & 100 & 0 & 3 & 9 & 3 & 0 & 15 \\
\hline & Total $^{*}$ & 15 & 67 & 60 & 34 & 4 & 180 \\
\hline
\end{tabular}

\footnotetext{
* Gimo and Torsburgen, inspected only in autumn 1993, are excluded
} 
Table 3. Occurrence of beetle species on pine trees sampled in autumn 1993.

\begin{tabular}{|c|c|c|c|c|c|c|c|c|c|c|c|c|c|}
\hline \multirow[t]{2}{*}{ Study area } & \multirow{2}{*}{$\begin{array}{c}\text { Number of } \\
\text { trees }\end{array}$} & \multicolumn{12}{|c|}{ Trees attacked by: } \\
\hline & & Tpin & Tlin & Piss & Hpal & Aaed & Rinq & Arus & Pqua & Msut & Pfas M & Mcya $\mathrm{F}$ & Ppol \\
\hline Brattfors & 48 & 31 & 0 & 1 & 0 & 18 & 10 & 3 & 1 & 3 & 0 & 0 & 0 \\
\hline Galtabäck+Skir & 11 & 3 & 0 & 0 & 0 & 0 & 2 & 4 & 0 & 0 & 0 & 0 & 0 \\
\hline Gimo & 28 & 7 & 0 & 2 & 1 & 0 & 7 & 2 & 0 & 1 & 0 & 0 & 0 \\
\hline Lenhovda & 30 & 5 & 5 & 3 & 1 & 6 & 6 & 0 & 1 & 0 & 1 & 0 & 0 \\
\hline Torsburgen & 39 & 6 & 0 & 1 & 0 & 8 & 4 & 2 & 0 & 2 & 0 & 6 & 3 \\
\hline Vakö myr & 25 & 5 & 0 & 4 & 0 & 0 & 1 & 0 & 0 & 0 & 0 & 0 & 0 \\
\hline Total (n) & 181 & 57 & 5 & 11 & 2 & 32 & 30 & 11 & 2 & 6 & 1 & 6 & 3 \\
\hline Total (\%) & & 31.5 & 2.8 & 6.1 & 1 & $\begin{array}{ll}11 & 17.7\end{array}$ & $7 \quad 16.6$ & 6.1 & 1 & 3.3 & 0.6 & 3.3 & $\begin{array}{ll}31.7 \\
\end{array}$ \\
\hline
\end{tabular}

Tpin = Tomicus piniperda; Tlin = Trypodendron lineatum; Piss = Pissodes sp.; Hpal = Hylurgops palliatus; Aaed $=$ Acanthocinus aedilis, Rinq $=$ Rhagium inquisitor, Arus $=$ Arhopalus rusticus; Pqua $=$ Pityogenes quadridens; Msut = Monocamus sutor, Pfas = Pogonochaerus fasciculatus; Mcya = Melanophila cyanea; Ppol = Polygraphus poligraphus

Table 4. Occurrence of beetle species on spruce trees sampled in autumn 1993.

\begin{tabular}{|c|c|c|c|c|c|c|c|c|c|c|c|}
\hline \multirow[t]{2}{*}{ Study area } & \multirow{2}{*}{$\begin{array}{c}\text { Number of } \\
\text { trees }\end{array}$} & \multicolumn{10}{|c|}{ Trees attacked by: } \\
\hline & & Pcha & Tlin & Ppol & Hpal & Tetr & Rinq & Piss & Msut & Pfas & Sund \\
\hline Brattfors & 0 & 0 & 0 & 0 & 0 & 0 & 0 & 0 & 0 & 0 & 0 \\
\hline Galtabäck+Skir & 21 & 9 & 3 & 17 & 1 & 1 & 3 & 1 & 0 & 0 & 0 \\
\hline Gimo & 13 & 9 & 2 & 0 & 4 & 1 & 2 & 0 & 0 & 1 & 0 \\
\hline Lenhovda & 8 & 5 & 1 & 4 & 0 & 0 & 0 & 0 & 0 & 0 & 0 \\
\hline Torsburgen & 15 & 0 & 0 & 8 & 0 & 0 & 0 & 0 & 2 & 0 & 2 \\
\hline Vakö myr & 33 & 4 & 0 & 17 & 1 & 3 & 2 & 1 & 0 & 0 & 0 \\
\hline Total (n) & 90 & 27 & 6 & 46 & 6 & 5 & 7 & 2 & 2 & 1 & 2 \\
\hline Total (\%) & & 30.0 & 6.7 & 51.1 & 6.7 & 5.6 & 7.8 & 2.2 & 2.2 & 1.1 & 2.2 \\
\hline
\end{tabular}

Pcha = Pityogenes chalcographus; Tlin = Trypodendron lineatum; Ppol = Polygraphus poligraphus; $\mathrm{Hpal}=$ Hylurgops palliatus; Tetr = Tetropium sp.; Ring = Rhagium inquisitor, Piss = Pissodes sp.; Msut = Monocamus sutor, Pfas = Pogonochaerus fasciculatus; Sund = Semanotus undatus.

Table 5. Occurrence of beetle species on pine trees sampled in autumn 1993 as related to tree vitality in spring 1993. Samples from the different study areas pooled; species codes as in Table 3.

\begin{tabular}{|c|c|c|c|c|c|c|c|c|c|c|c|c|c|}
\hline \multirow{2}{*}{$\begin{array}{l}\text { Fresh biomass in } \\
\text { spring } 1993, \%\end{array}$} & \multirow{2}{*}{$\begin{array}{c}\text { Number of } \\
\text { trees }\end{array}$} & \multicolumn{12}{|c|}{ Trees attacked by: } \\
\hline & & Tpin & Tlin & Piss & Hpal & Aaed & Rinq & Arus & Pqua & Msut & Pfas & Mcya & Ppol \\
\hline $0 \%$ & 20 & 4 & 2 & 1 & 1 & 8 & 13 & 1 & 1 & 2 & 0 & 0 & 0 \\
\hline $10-30 \%$ & 59 & 30 & 3 & 7 & 0 & 16 & 6 & 4 & 1 & 1 & 1 & 0 & 0 \\
\hline $40-60 \%$ & 11 & 4 & 0 & 0 & 0 & 0 & 0 & 0 & 0 & 0 & 0 & 0 & 0 \\
\hline $70-90 \%$ & 24 & 6 & 0 & 0 & 0 & 0 & 0 & 2 & 0 & 0 & 0 & 0 & 0 \\
\hline $100 \%$ & 0 & 0 & 0 & 0 & 0 & 0 & 0 & 0 & 0 & 0 & 0 & 0 & 0 \\
\hline Total $^{*}$ & 114 & 44 & 5 & 8 & 1 & 24 & 19 & 7 & 2 & 3 & 1 & 0 & 0 \\
\hline
\end{tabular}

* Gimo and Torsburgen, inspected only in autumn 1993, are excluded 


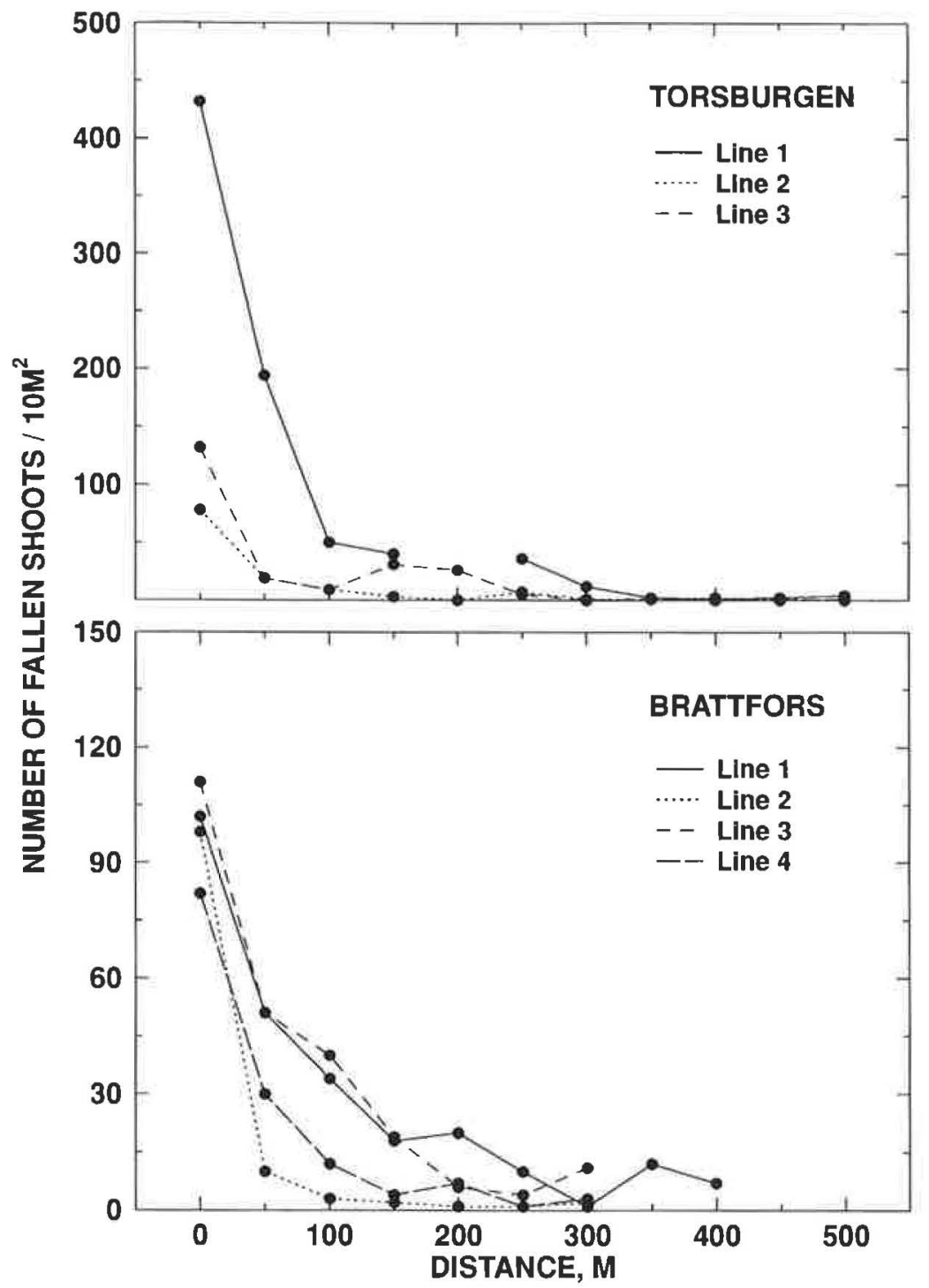

Fig. 2. The number of fallen shoots attacked by $T$. piniperda along transects from the edge of the burned forest into surrounding pine forest at Torsburgen and Brattfors in 1993 (fallen shoots collected in autumn 1993 and spring 1994 were pooled for each sample plot; note different scales on $\mathrm{Y}$ axis; one sample plot excluded at Torsburgen due to open space).
Two species were seen only at the Gotland site: Semanotus undatus (Linnaeus) (spruce) and Melanophila cyanea (Fabricius) (pine).

Most beetle species clearly preferred the dead or dying trees (Tables 5 and 6). However, $T$. piniperda and $A$. rusticus also attacked pines with more than half of the foliage left; as $\operatorname{did} P$. poligraphus, $P$. chalcographus and Tetropium (castaneum (Linnaeus) or fuscum (Fabricius)) on spruce.

\subsection{Survey lines}

The number of fallen shoots due to Tomicus attack declined quickly along the survey lines at Brattfors and Torsburgen (Fig. 2). Although figures are low beyond $100 \mathrm{~m}$ from the fire area edge, they indicate that pine shoot beetle had dispersed several hundred meters into the surrounding pine forests. At Torsburgen, shoot numbers were close to zero from $300 \mathrm{~m}$ distance, and 
similar to levels seen in well-managed forests.

No incidence of dead or dying trees due to bark beetle attack were seen in the vicinity of the shoot plots.

\subsection{Field observations}

The fire-dependent buprestid, Oxypteris (Melanophila) acuminata (Degeer), was not recorded on the sample trees. However, directional species-hunting revealed that it was present at three of the study areas: Skir (own observations), Gimo (L-O Wikars, pers. comm.) and Vakö (M. Sörenson, pers. comm.).

We also looked for the fire-dependent ground beetles Sericoda (Agonum) quadripunctata (Degeer) and Pterostichus quadrifoveolatus (Letzner) The former was seen in varying numbers on all sites (except Brattfors), whereas the latter was seen only at Galtabäck and Vakö.

\section{Discussion}

As this study so far covers only the first year colonization of the burned trees, little can be concluded about their suitability as brood material for bark- and wood-living insects.

Although our study was not designed to estimate the impact of fire on trees of different species and size, it is obvious that spruce trees were clearly more sensitive to fire-damage than pines. Also, small pines displayed poor fire resistance, whereas large pines often escaped deadly damage. This is well known and well documented in fire-ecological literature, and bark thickness is obviously important for tree survival (Gardiner 1957, Kozlowski \& Ahlgren 1974, Kolström \& Kellomäki 1993).

Many of the trees were not attacked at all, and for two different reasons. Some trees were so heavily burned that the primary colonizers could not breed in them due to the fact that all the phloem was destroyed by the fire. On the other hand, some of the less fire-damaged trees were still resistant enough to withstand beetle attacks. This finding agrees with earlier observations (Ehnström 1991). Thus, one important conclusion from the forest protection point of view, is that far from all burned trees are or can be utilized by bark beetles and other forest pests. However, recurrent beetle attack on weak trees may gradually render them susceptible.

Most attacks occurred on trees with fresh phloem and less than $30 \%$ green foliage left. Thus, the colonizing beetles preferred dead, dying or severely weakened trees. However, a few species displayed a more aggressive behaviour in attacking more vigourous trees (with more green foliage). These potentially more dangerous species were: $T$. piniperda and A. rusticus on pine, and $P$. poligraphus, $P$. chalcographus and Tetropium sp. on spruce. Of these, all three spruce-living species are known as capable tree killers under certain circumstances (Trägårdh 1939, Saalas 1949, Juutinen 1958, Lekander 1959, Butovitsch 1971). T. piniperda is generally con-

Table 6. Occurrence of beetle species on spruce trees sampled in autumn 1993 as related to tree vitality in spring 1993. Samples from the different study areas pooled; species codes as in Table 4.

\begin{tabular}{|c|c|c|c|c|c|c|c|c|c|c|c|}
\hline \multirow{2}{*}{$\begin{array}{l}\text { Fresh biomass in } \\
\text { spring } 1993, \%\end{array}$} & \multirow{2}{*}{$\begin{array}{c}\text { Number of } \\
\text { trees }\end{array}$} & \multicolumn{10}{|c|}{ Trees attacked by: } \\
\hline & & Pcha & Tlin & Ppol & Hpal & Tetr & Rinq & Piss & Msut & Pfas & Sund \\
\hline $0 \%$ & 32 & 8 & 4 & 22 & 2 & 1 & 4 & 1 & 0 & 0 & 0 \\
\hline $10-30 \%$ & 18 & 6 & 0 & 12 & 0 & 2 & 1 & 1 & 0 & 0 & 0 \\
\hline $40-60 \%$ & 5 & 4 & 0 & 3 & 0 & 1 & 0 & 0 & 0 & 0 & 0 \\
\hline $70-90 \%$ & 2 & 0 & 0 & 1 & 0 & 0 & 0 & 0 & 0 & 0 & 0 \\
\hline $100 \%$ & 5 & 0 & 0 & 0 & 0 & 0 & 0 & 0 & 0 & 0 & 0 \\
\hline Total $^{*}$ & 62 & 18 & 4 & 38 & 2 & 4 & 5 & 2 & 0 & 0 & 0 \\
\hline
\end{tabular}

\footnotetext{
* Gimo and Torsburgen, inspected only in autumn 1993, are excluded.
} 
sidered to be a secondary bark beetle, not capable of attacking healthy trees unless population densities are extremely high (for references, see Långström \& Hellqvist 1993). However, the species was very common on burned trees in northernmost Sweden (Ehnström 1977a,b). Little is known about the aggressiveness of $A$. rusticus, but Saalas (1949) mentions that it may attack fairly healthy trees.

The assembly of attacking beetles was, with a few exceptions, fairly trivial and predictable. All the recorded species are common bark- and wood inhabiting beetle species, known as primary colonizers of fresh conifer timber or dying trees (see e.g. Trägårdh 1939, Saalas 1949). One exception was $A$. rusticus which, at some sites, occurred in larger numbers than normally seen. This was especially the case at the Gotland site, which also was the only site for $S$. undatus (spruce) and $M$. cyanea (spruce). The low frequencies of $M$. sutor were surprising as this species has been reported to be attracted to firedamaged trees (Forsslund 1934). Also, the low numbers of I. typographus (which was seen in a few trees outside sample plots) was noteworthy. Obviously, fire-damaged spruce trees are not very suitable for this species. In addition, many of the suitable trees might have been colonized by the late-flying $P$. poligraphus soon after the fire, and hence were not been available for attacks by $I$. typographus in the following spring.

The fire-dependent buprestid $O$. acuminata was observed in three of the study areas, and always outside the sample plots. Thus, is becomes obvious that we have to add habitat-directed "species hunting" to our arsenal of study techniques if we want to get data (at least presence/absence data) on these highly specialized species. Although this species is one of the "firespecialists" (Lundberg 1984, Wikars 1992, 1994, and references therein), it occurs erratically, and was reported neither by Ehnström (1991) nor by Muona \& Rutanen (1994).

As we did not systematically search for the two ground beetles $S$. quadripunctata and $P$. quadrifoveolatus at the study areas and plots, their abundance cannot be quantified. However, we found the former in more sites and in higher numbers than the latter. These observations agree with other studies in Sweden (Lundberg 1984,
Ehnström 1991, Wikars 1992), whereas Muona \& Rutanen (1994) reported the former but not the latter species.

No signs of excessive dispersal of bark beetles from the burned areas into surrounding conifer forests were seen. No incidence of increased tree mortality due to bark beetles (or other causes) could be seen along the survey lines laid out for counting fallen shoots. The pattern of fallen shoots was similar to what has been seen elsewhere around a local beetle source (Nilsson 1974, Långström \& Hellqvist unpubl. data), and hence is by no means alarming.

In conclusion, there is, so far, little concern for bark beetle outbreaks emanating from burned forests, as many of the burned trees are unsuitable for bark beetles. However, the continued inspections in 1994 indicate that the situation has not yet stabilized with respect to tree vigour, and hence, new trees of declining vigour may become available for beetle attack in years to come. Windthrows in surviving stands with weakened roots due to the fire may also create favourable brood material for bark beetles. Thus, primary colonizers will find new trees to attack in coming years. At the same time, secondary cambial eaters will initiate a wave of secondary colonization on trees killed by fire or by the beetles. Thus, future inspections will result in a more diverse assembly of species on the burned trees.

Acknowledgements. We thank "Stiftelsen Oscar och Lili Lamms minne" for financial support, the landowners and the county government boards for permission to work in the forest reserves, Rune Axelsson for field assistance and Nigel Rollison for improving the English.

\section{References}

Berg, Å., Ehnström, B., Gustafsson, L., Hallingbäck, T., Jonsell, M., \& Weslien, J. 1994: Threatened plant, animal and fungus species in Swedish forests: Distribution and habitat associations. - Conserv. Biol. 8:718-731.

Butovitsch, V. 1971: Undersökningar över skadeinsektemas uppträdande i de stormhärjade skogarna i mellersta Norrlands kustland åren 1967-69. (Untersuchungen über das Auftreten von Forstschädlingen in den von Schneestürmen heimgesuchten Fichtenwäldern des Küstengebiets der Provinz Västernorrland in den Jahren 1967-69). - Royal Coll. For., Dept of For. Zool., Res. Notes 8:1-204 (in Swedish, German summary). 
Ehnström, B. 1977 a: Reivoprojektet. Den brända skogens ekologi. Undersökningar över träinsekter 1976. [The Reivo-project. The ecology of the burned forest. Studies on wood insects 1976]. - Skogshögskolan, Avd. Skogsentomologi, Rapp. 4:1-11 (in Swedish).

- 1977: b: Reivoprojektet. Den brända skogens ekologi. Undersökningar över träinsekter 1977. [The Reivoproject. The ecology of the bumed forest. Studies on wood insects 1977]. - Skogshögskolan, Avd. Skogsentomologi, Rapp. 5:1-10 (in Swedish).

- 1991: Många insekter gynnas. [Many insects are favoured]. - Skog \& Forskning 4:47-52 (in Swedish).

Ehnström, B., Gärdenfors, U., \& Lindelöw, Å. 1993: Rödlistade evertebrater i Sverige. [Red-listed evertebrates in Sweden]. — Databanken för hotade arter, Uppsala:169 (in Swedish).

Essen, P. A., Ehnström, B., Ericson, L., \& Sjöberg, K. 1992: Boreal forests the focal habitats of Fennoscandia. Hansson L. (ed.): Nature conservation by ecological principles, applications in temperate and boreal environments. - Elsevier, London \& New York. pp. 252-325.

Forsslund, K-H. 1934: Tallbockens (Monochamus sutor L.) uppträdande på brandfält i norra Sverige sommaren 1933. (Das Auftreten des Schusterbocks (Monochamus sutor L.) auf Brandflächen in Nordschweden im Sommer 1993). - Sv. Skogsvårdsfören. Tidskr. 12:23-38 (in Swedish, German summary).

Gardiner, L. M. 1957: Deterioration of fire-killed pine in Ontario and causal wood-boring beetles. - Can. Entomol. 89: 241-263.

Heliövaara, K., \& Väisänen, R. 1984: Effects of modern forestry on northwestern European forest invertebrates: a synthesis. - Acta For. Fenn, 189:1-32.

Juutinen, P. 1958: Tutkimuksia metsätuhojen, etenkin hyönteisvaurioiden merkityksestä Pohjois-Suomen kuusikoissa. (Untersuchungen über die Bedeutung der Waldverheerungen, insbesondere der Insektenschädigungen, in der Fichtenbeständen Nordfinnlands). — Comm. Inst For. Fenn. 50.(1):1-92 (in Finnish, German summary).
Kolström, T., \& Kellomäki, S. 1993: Tree survival in wildfires. - Silva Fennica 27:277-281.

Kozlowski, T. T. \& Ahlgren, C. E. 1974: Fire and ecosystems (Eds). - Academic Press, New York, 542 pp.

Lekander, B. 1959: Der doppeläugige Fichtenbastkäfer, Polygraphus poligraphus L. - Medd. Stat. Skogsf. Inst. 48.9:1-127.

Linder, P., \& Östlund, L. 1992: Förändringar i Sveriges boreala skogar 1870-1991. (Changes in the boreal forests of Sweden 1870-1991). - Sv. Bot. Tidskr. 86:199-215 (in Swedish, English summary).

Lundberg, S. 1984: Den brända skogens skalbaggsfauna i Sverige. [The beetle fauna of burnt forest in Sweden]. — Entomol. Tidskr. 105:129-141 (in Swedish).

Långström, B. \& Hellqvist, C. 1993: Induced and spontaneous attacks by Tomicus piniperda and $\mathrm{T}$. minor on young Scots pine trees: tree mortality and beetle performance. - J. Appl. Entomol. 115:25-36.

Muona, J., \& Rutanen, I. 1994: The short-term impact of fire on the beetle fauna in the boreal coniferous forest. - Ann. Zool. Fenn. 31:109-121.

Nilsson, S. 1974: Märgborreskador vid överlagring av tallvirke (Damage caused by Blastophagus piniperda hatched in stored pine wood). - Royal Coll. For., Dept Operat. Efficiency, Res. Notes 74:1-35 (in Swedish, English summary).

Saalas, U. 1949: Suomen metsähyönteiset. [Forest insects of Finland]. - Porvoo, Helsinki. 719 pp. (In Finnish).

Silfverberg, H. 1992: Enumeratio Coleopterorum Fennoscandiae, Daniae et Baltiae. - Helsinki 1-94.

Trägårdh, I. 1939: Sveriges skogsinsekter. [Forest insects of Sweden]. - Stockholm 508 pp. (in Swedish).

Wikars, L.-O. 1993: Skogsbränder och insekter. (Forest fires and insects). - Entomol. Tidskr. 113: 1-11. (in Swedish, English summary).

Wikars, L. O. 1994: Effects of fire and ecology on fireadapted insects. - Univ. Uppsala, Dept zool., Sect. Entomol., Introd. Res. Essay 12: 1-22.

Zackrisson, O. 1977: Influence of forest fires on the north Swedish boreal forest. - Oikos 29:22-32. 